\title{
Meningkatkan Keterampilan Menulis Karangan Deskripsi Siswa dengan Menggunakan Media Gambar di Kelas X IPA SMAN 4 Sampang
}

\author{
Dewi Wahyuni \\ SMAN 4 Sampang \\ Dwahyuni899@yahoo.com
}

Gambar merupakan salah satu media pembelajaran yang digunakan peneliti untuk meningkatkan kemampuan keterampilan menulis karangan deskripsi siswa. Penelitian ini bertujuan untuk mengukur bagaimana media gambar dapat meningkatkan kemampuan keterampilan menulis karangan deskripsi siswa. Jenis penelitian ini merupakan jenis penelitian tindakan kelas yang mencakup tahap perencanaan, tahap implementasi, tahap observasi, dan tahap refleksi. Data diambil melalui rubrik penilaian menulis karangan deskripsi, kuesioner, dan ceklis observasi. Data diperoleh melalui pre-study, siklus 1, dan siklus 2 . Pada tahap pre-study, banyak siswa yang mengalami kesulitan memulai dan mengembangkan idenya sehingga mereka kurang minat untuk menulis karangan deskripsi. Disamping itu, peneliti juga menemukan hanya 10 siswa yang mencapai nilai KKM ( $\geq 76)$ atau $31 \%$ persentase sukses. Sedangkan pada siklus kesatu, peneliti menemukan 21 siswa yang mencapai nilai KKM ( $\geq 76)$ atau $66 \%$ persentase sukses. Berdasarkan temuan pada siklus kesatu, peneliti dan guru kelas merevisi pembelajaran dengan menambahkan strategi pembelajaran menulis karangan deskripsi dengan bantuan media gambar. Pada siklus kedua, peneliti menemukan 27 siswa yang mencapai nilai KKM $(\geq 76)$ atau 84\% persentase sukses. Peneliti dan guru kelas juga menemukan bahwa siswa memberikan respon yang lebih baik daripada sebelumnya, banyak siswa termotivasi untuk aktif di kelas sehingga mereka memiliki sikap percaya diri menulis karangan deskripsi. Dari hasil penelitian diatas menunjukkan bahwa penggunaan media gambar dapat meningkatkan keterampilan menulis karangan deskripsi siswa kelas X IPA SMAN 4 Sampang.

Kata Kunci: Keterampilan, Karangan Deskripsi, Media Gambar. 


\section{Latar belakang}

Keterampilan menyimak, berbicara, membaca, dan menulis merupakan jenis keterampilan berbahasa yang saling bersinergi. Keterampilan menulis merupakan salah satu keterampilan yang sangat penting karena keterampilan tersebut masih dipandang sebagai salah satu bentuk komunikasi yang efektif dan ekonomis (Khotimah \& Rosliana, 2017: 17).

Fachrurrazy (2012: 88) mengatakan bahwa menulis merupakan keterampilan produktif dan aktif, yaitu menulis dapat menghasilkan Bahasa daripada menerimanya.

Penyampaian ide atau pendapat melalui keterampilan menulis juga menjadi bentuk komunikasi dua arah yang efektif tanpa harus bertatap muka langsung dengan lawan bicaranya. Orang-orang memiliki banyak waktu untuk berfikir sebelum mereka menulis, menuangkan dan mengembangkan ide, memilih kata-kata, membaca kembali tulisannya, mempertimbangkan, kemudian memperbaikinya.

Tarigan (2008: 3) berpendapat bahwa menulis merupakan suatu keterampilan berbahasa yang menjadi sebuah komunikasi secara tidak langsung. Menulis merupakan suatu kegiatan yang produktif dan ekspresif. Dalam kegiatan menulis ini, penulis haruslah terampil memanfaatkan grafolegi, struktur bahasa, dan kosa kata. Keterampilan menulis tidak dapat diperoleh begitu saja, tetapi harus dimulai banyak latihan dan praktik yang teratur.

Suparno dan Yunus (2007: 1.3) mengemukakan bahwa menulis dapat diartikan sebagai suatu kegiatan penyampaian pesan atau ide dengan menggunakan bahasa tulis. Pesan adalah isi yang terkandung dalam suatu tulisan.
Tulisan merupakan sebuah simbol bahasa yang dapat dilihat dan disepakati pemakaiannya.

Di dalam dunia edukasi, menulis merupakan suatu keterampilan yang memiliki peranan penting. Tingkat kesulitan di dalam menulis disebabkan adanya penguasaan unsur kebahasaan dan unsur di luar kebahasaan yang akan menjadi isi karangan.

Siswa Sekolah Menengah Atas seharusnya sudah mampu mengekspresikan gagasan, pikiran, dan perasaannya secara tertulis. Namun pada kenyataannya, keterampilan menulis belum dapat terlaksana sepenuhnya. Pembelajaran keterampilan menulis di SMA Negeri 4 Sampang masih belum efektif karena kurangnya praktik menulis oleh siswa sehingga mereka sulit menuangkan ide atau gagasannya dalam bentuk tulisan. Siswa juga merasa kesulitan menumbuhkan imajinasinya ketika dihadapkan pada suatu topik yang tidak dikenalnya. Disamping itu, penulis atau peneliti juga menemukan nilai keterampilan menulis mereka masih dibawah KKM (Kriteria Ketuntasan Minimum) atau $<75$.

Berdasarkan situasi diatas, penulis tertarik mengadakan sebuah penelitian yang berjudul "Meningkatkan Keterampilan Menulis Karangan Deskripsi Siswa dengan Menggunakan Media Gambar di Kelas X IPA SMAN 4 Sampang.

Inti permasalahan diatas yang harus diselesaikan adalah membuat pelajar mampu menulis karangan deskripsi dengan cara menumbuhkan imajinasi yang dimilikinya, jika dihadapkan pada topik yang belum dikenalnya. Untuk itu, diperlukan suatu inovasi pembelajaran sebagai upaya peningkatan kualitas pembelajaran menulis, khususnya menulis karangan deskripsi melalui media gambar. 
Menurut Riyanto (2002: 24). Media gambar juga menjadi salah satu tanda atau simbol yang memungkinkan terjadinya komunikasi antara pelukis dan pembaca.

Media gambar dapat diwujudkan secara visual sebagai curahan ataupun pikiran yang bentuknya bermacam-macam seperti lukisan, potret, slide, film, dan lain-lain (Hamalik, 2004: 95).

Tujuan penelitian ini adalah untuk meningkatkan keterampilan menulis karangan deskripsi siswa dengan menggunakan media gambar. Dengan bantuan media gambar diharapkan dapat menumbuhkan minat dan imajinasi siswa menulis karangan deskripsi.

\section{Metode}

Fokus pada penelitian diatas, penulis bermaksud meningkatkan keterampilan menulis karangan deskripsi siswa dengan bantuan media gambar. Oleh karena itu, rancangan penelitian ini menggunakan jenis penelitian tindakan kelas (PTK).

"Pengembangkan strategi pembelajaran inovatif yang dapat membantu meningkatkan keberhasilan pembelajaran bahasa siswa merupakan tujuan utama Penelitian Tindakan Kelas untuk Pembelajaran Bahasa” (Latif, 2011: 145).

Adapun jenis penelitian tersebut meliputi tahap perencanaan, tahap implementasi, tahap pengamatan (pengumpulan data), serta tahap refleksi (proses analisis data).

\section{Tahap perencanaan}

Pada tahap perencanaan, peneliti mempersiapkan strategy pembelajaran menulis karangan deskripsi dengan bantuan media gambar. Persiapan tersebut mencakup rencana pelaksanaan pembelajaran (RPP) serta kriteria kesuksesan pembelajaran di kelas.

\section{-Merancang strategy pembelajaran dengan bantuan gambar}

Berdasarkan hasil survey, penulis membutuhkan sebuah rancangan strategy pembelajaran untuk membantu meningkatkan keterampilan menulis karangan deskripsi siswa dengan bantuan gambar. Penulis memilih media gambar karena telah diyakini bahwa siswa dapat mengekspresikan ide, perasaan, dan emosi mereka lewat tulisan deskripsi.

\section{-Merancang rencana pelaksanaan pembelajaran}

Rencana pelaksanaan pembelajaran (RPP) mencakup standar kompetensi, kompetensi dasar, indikator, tujuan, materi dan metode pembelajaran, media instruksi dan sumber, prosedur kegiatan pembelajaran, penilaian.

\section{-Kriteria kesuksesan pembelajaran}

Pembelajaran dapat dikatakan sukses jika hasil keterampilan menulis deskripsi siswa telah memenuhi standar KKM serta atmosfer kelas semakin efektif.

Berikut tabel kriteria kesuksesan pembelajaran

\begin{tabular}{|l|l|l|}
\hline Kriteria sukses & Sumber data & Instrumen \\
\hline $\begin{array}{l}\text { Nilai KKM } \\
(75)\end{array}$ & $\begin{array}{l}\text { Hasil } \\
\text { keterampilan } \\
\text { menulis } \\
\text { karangan } \\
\text { deskripsi siswa }\end{array}$ & $\begin{array}{l}\text { Penilaian } \\
\text { keterampilan } \\
\text { menulis }\end{array}$ \\
\hline $\begin{array}{l}\text { Hampir semua } \\
\text { siswa menilai }\end{array}$ & $\begin{array}{l}\text { Komentar siswa } \\
\text { terhadap }\end{array}$ & Kuesioner \\
\hline
\end{tabular}


pembejaran

dengan positif pembelajaran di

kelas

Penilaian terhadap keterampilan menulis karangan deskripsi meliputi struktur umum (identifikasi dan deskripsi), tatabahasa, mekanik, dan gaya penulisan.

\section{Tahap implementasi}

$\begin{array}{llr}\text { Berdasarkan } & \text { rencana } & \text { pelaksanaan } \\ \text { pembelajaran, seorang } & \text { guru telah } \\ \text { mengimplementasikan } & \text { pembelajaran }\end{array}$ karangan deskripsi dengan memperkenalkan siswa terhadap susunan penulisan teks tersebut. Kemudian meminta siswa untuk menggambarkan ide yang sesuai dengan tema yang diberikan oleh penulis atau peneliti. Pada pertemuan selanjutnya, penulis atau peneliti memberikan siswa sebuah media gambar, dan meminta siswa mengarang berdasarkan gambar. Pada saat siswa diperkenalkan gambar untuk menulis karangan deskripsi, siswa merasa tertarik, merasa lebih mudah berimajinasi untuk menulis karangan deskripsi tersebut.

\section{Tahap pengamatan}

Selama proses pengamatan, penulis atau peneliti mengumpulkan data baik verbal maupun numerik. Data numerik telah diperoleh melalui hasil keterampilan menulis karangan deskripsi siswa dengan bantuan gambar, sedangkan data verbal telah diperoleh melalui hasil kuesioner dan ceklis pengamatan selama proses belajar mengajar di kelas.

\section{Tahap refleksi}

Penulis atau peneliti menganalisis data berdasarkan dua jenis data yaitu verbal data untuk memenuhi kesuksesan atmosfer kelas

\begin{tabular}{|l|l|l|}
\hline $\begin{array}{l}\text { Semua siswa } \\
\text { termotivasi }\end{array}$ & $\begin{array}{l}\text { Keterlibatan } \\
\text { siswa }\end{array}$ & $\begin{array}{l}\text { Ceklis } \\
\text { pengamatan }\end{array}$ \\
\hline
\end{tabular}

seperti hasil obervasi dan kuesioner yang mencakup keterlibatan serta respon siswa selama proses belajar mengajar berlangsung. Dan numerical data untuk memenuhi standar KKM keterampilan menulis deskripsi siswa. Jika hasil dari kedua data tersebut menunjukkan kriteria kesuksesan pembelajaran di kelas, maka penelitian tindakan kelas diberhentikan, namun berdasarkan temuan pada siklus pertama telah menunjukkan kriteria kesuksesan belum tercapai, maka penelitian ini perlu dilanjutkan ke tahap berikutnya yaitu siklus kedua.

\section{Hasil penelitian}

\begin{tabular}{|l|l|l|l|l|}
\hline $\begin{array}{l}\text { Jumlah } \\
\text { siswa }\end{array}$ & $\begin{array}{l}\text { Siswa yang } \\
\text { mendapatkan } \\
\text { nilai }<75\end{array}$ & $\begin{array}{l}\text { Siswa yang } \\
\text { mendapatkan } \\
\text { nilai } \geq 75\end{array}$ & $\begin{array}{l}\text { Persentase } \\
\text { sukses }\end{array}$ & $\begin{array}{l}\text { Nilai } \\
\text { rata- } \\
\text { rata }\end{array}$ \\
\hline 32 & 22 & 10 & $31 \%$ & 69,21 \\
\hline
\end{tabular}

Berdasarkan hasil survey dan kuesioner pada tahap pre-study, banyak siswa yang mengalami kesulitan memulai dan mengembangkan idenya sehingga mereka kurang minat untuk menulis karangan deskripsi.

Atas dasar temuan tersebut, peneliti atau penulis mencoba menerapkan media gambar 28 i tolak ukur untuk memunculkan dan uuнumbangkan ide siswa menulis karangan deskripsi.

Pada tahap siklus pertama, peneliti atau penulis telah menemukan hasil keterampilan menulis karangan deskripsi siswa dengan menggunakan media gambar menunjukkan persentase sukses $66 \%$ dan nilai rata-rata 73,90 . 
Berikut tabel hasil keterampilan menulis karangan deskripsi siswa dengan bantuan media gambar:

\begin{tabular}{|l|l|l|l|l|}
\hline $\begin{array}{l}\text { Jumlah } \\
\text { siswa }\end{array}$ & $\begin{array}{l}\text { Siswa yang } \\
\text { mendapatkan } \\
\text { nilai }<75\end{array}$ & $\begin{array}{l}\text { Siswa yang } \\
\text { mendapatkan } \\
\text { nilai } \geq 75\end{array}$ & $\begin{array}{l}\text { Persentase } \\
\text { sukses }\end{array}$ & $\begin{array}{l}\text { Nilai } \\
\text { rata- } \\
\text { rata }\end{array}$ \\
\hline 32 & 11 & 21 & $66 \%$ & 73,90 \\
\hline
\end{tabular}

Dari hasil kuesioner siklus 1 menunjukkan siswa memberikan respon positif terhadap implementasi media gambar, siswa juga mulai menunjukkan minat, keaktifan, dan sikap percaya diri di dalam menulis. Namun beberapa masalah masih ditemukan, seperti penggunaan EYD dan tanda baca kurang tepat. Sementara hasil pengamatan menunjukkan bahwa siswa yang memperhatikan instruksi guru hanya $60 \%$, merespon instruksi guru 55\%, partisipasi di dalam kelompok $65 \%$.

Berdasarkan hasil siklus pertama, penulis atau peneliti dan guru kelas berencana untuk melanjutkan penelitiannya ke siklus berikutnya karena indikator kriteria sukses belum tercapai.

Pada siklus kedua, hasil keterampilan menulis karangan deskripsi dengan menggunakan media gambar menunjukkan persentase sukses $84 \%$, sedangkan nilai ratarata 78,12 .

Berikut tabel hasil keterampilan menulis karangan deskripsi dengan bantuan media gambar pada siklus kedua:

\begin{tabular}{|l|l|l|l|l|}
\hline $\begin{array}{l}\text { Jumlah } \\
\text { siswa }\end{array}$ & $\begin{array}{l}\text { Siswa yang } \\
\text { mendapatka } \\
\text { n nilai }<75\end{array}$ & $\begin{array}{l}\text { Siswa yang } \\
\text { mendapatka } \\
\text { n nilai } \geq 75\end{array}$ & $\begin{array}{l}\text { Persentase } \\
\text { sukses }\end{array}$ & $\begin{array}{l}\text { Nilai } \\
\text { rata- } \\
\text { rata }\end{array}$ \\
\hline 32 & 5 & 27 & $84 \%$ & 78,12 \\
\hline
\end{tabular}

Berdasarkan hasil temuan pada siklus kedua, penulis atau peneliti menyimpulkan bahwa siswa memberikan respon yang lebih baik daripada sebelumnya, banyak siswa termotivasi untuk aktif di kelas sehingga mereka memiliki sikap percaya diri menulis karangan deskripsi, hal ini juga disebabkan adanya tambahan strategy implementasi media gambar terhadap karangan deskripsi.

Sementara hasil pengamatan menunjukkan bahwa siswa yang memperhatikan instruksi guru hanya $85 \%$, merespon instruksi guru $80 \%$, partisipasi di dalam kelompok $75 \%$.

Hasil kuesioner dan observasi digunakan untuk mengetahui atmosfer kelas pada mata pelajaran menulis karangan deskripsi dengan menggunakan media gambar.

Hasil siklus kedua telah mencapai standar minimum ketuntasan/ KKM $(\geq 75)$. Peneliti dan guru kelas menganggap bahwa penelitian tindakan kelas tidak perlu dilanjutkan ke siklus berikutnya karena indikator kriteria kesuksesan sudah tercapai.

\section{Diskusi}

Pada hasil pre-study, siswa mengalami kesulitan untuk memulai menulis karangan deskripsi, bagaimana mereka mengembangkan idenya tanpa bantuan gambar, disamping itu juga kurangnya minat dan percaya diri siswa untuk menulis. Setelah mereka mendiskusikan permasalahan yang siswa hadapi, penulis atau peneliti dan guru kelas mengimplementasikan media gambar sebagai salah satu teknik pembelajaran untuk meningkatkan keterampilan menulis karangan deskripsi siswa.

Pada siklus pertama, beberapa siswa masih mengalami kesulitan untuk memulai menulis karangan deskripsi, beberapa diantaranya mereka belum paham penggunaan EYD dan 
tanda baca yang kurang tepat. Pada siklus ini peneliti dan guru kelas tidak menemukan kriteria sukses dalam penelitian tindakan kelas. Oleh karena itu, peneliti dan guru kelas mengevaluasi kelemahan strategi pembelajaran pada siklus pertama. Peneliti dan guru kelas merevisi rencana pelaksanaan pembelajaran dengan menambahkan strategi baru pada pembelajaran menulis karangan deskripsi.

Pada siklus kedua, revisi rencana pelaksanaan pembelajaran dengan tambahan Strategi baru tersebut mencakup; pemanfaatan power point dalam penyajian materi, memberikan siswa game tentang deskripsi hewan, benda, dan lain-lain, penggunaan EYD dan tanda baca yang tepat.

Implementasi hasil revisi rencana pelaksanaan pembelajaran telah mampu mencipatkan atmosfer kelas yang baik, banyak siswa yang antusias dan percaya diri menulis karangan deskripsi. Sedangkan nilai keterampilan menulis karangan deskripsi siswa semakin meningkat.

Hasil penelitian pada siklus kedua telah menunjukkan kriteria sukses dalam penelitian tindakan kelas, atas dasar hasil siklus kedua peneliti dan guru kelas mengakhiri penelitiannya.

\section{Kesimpulan dan Saran}

Hasil penelitian diatas dapat disimpulkan bahwa penggunaan media gambar dapat meningkatkan keterampilan menulis karangan deskripsi siswa kelas X IPA SMAN 4 Sampang, dengan beberapa tambahan strategi pembelajaran di kelas. Hal tersebut dapat dibuktikan dari hasil prestudy, proses pembelajaran pada siklus kesatu dan kedua sudah mulai ada peningkatan hasil pembelajaran. Pada siklus kedua pembelajaran menulis karangan deskripsi sudah mencapai kriteria sukses penelitian tindakan kelas, maka penelitian tersebut tidak perlu dilanjutkan ke siklus berikutnya.

Pengalaman penelitian ini diharapkan dapat menjadi solusi utama bagi guru yang memiliki permasalahan pembelajaran Bahasa serta keadaan kelas yang kurang efektif sehingga dapat menciptakan proses belajar mengajar yg lebih kreatif dan menarik.

\section{Referensi}

Fachrurrazy. 2012. Teaching English as a Foreign Language for Teachers in Indonesia. Malang: State University of Malang Press.

Hamalik, Oem ar. 2004. Media Pendidikan. Jakarta:Universitas Terbuka.

Khotimah, K. \& Rosliana, E. 2017. Penggunaan Media Gambar Untuk Meningkatkan Ketrampilan Menulis Karangan Deskripsi Pada Siswa Kelas VII SMP Negeri 2 Petarukan. Jurnal Pendidikan Cakrawala, XI (2): 16-24.

Latief, M.A. 2011. Research Methods on Language Learning: An Introduction. Malang: State University of Malang Press.

Riyanto, 2002. Strategi Pembelajaran (Berorientasi Standar Proses Pendidikan). Jakarta: Kencana. Suparno dan Yunus, M. 2007. Keterampilan Dasar Menulis. Jakarta: Universitas Terbuka.

Tarigan, H.G. 2008. Menulis sebagai Keterampilan Berbahasa. Bandung: Angkasa. 